\title{
NIH panel to monitor peer review in action
}

Washington. The US National Institutes of Health (NIH) are to set up a panel of university scientists and NIH officials to monitor the way in which peer review is applied to NIH grant applications.

The new panel will develop peer review policy for all parts of NIH, and will coordinate the activities of the Division of Research Grants (DRG) - which is responsible for the evaluation of about 80 per cent of NIH grant applications - with peer review administered directly by the various $\mathrm{NIH}$ institutes and centres.

It will also periodically scrutinize the various DRG study sections to ensure they are operating fairly and efficiently and are keeping up with new developments in research.

"The panel will be a place where all issues relating to peer review at NIH can be discussed, and people with broad concerns about peer review can be heard," says Wendy Baldwin, deputy director for extramural research at NIH, and chair of the new oversight group. "It is not intended to micromanage the DRG, or to examine individual complaints of abuses in the peer review process."

The formation of the oversight body had been strongly recommended by a group of scientists from both inside and outside $\mathrm{NIH}$ to set up to review the administrative structure of the DRG. The committee was chaired by Marvin Cassman, director of the National Institute of General Medical Sciences (NIGMS), and began its work in Varmus: setting up January. It reported its oversight body. conclusions to Harold

Varmus, the director of NIH, in mid-May, and Varmus announced his decision to create the oversight panel last week.

Cassman says that his committee found no major fault with the internal organization of DRG, which has been an independent division reporting directly to the NIH director since 1946. But it did find several problems that an oversight panel could address, including a feeling that evaluation standards are not consistent across the DRG's study sections and institute review groups. "We felt that an oversight board would help to unify the peer review process for all of NIH, and allow much greater input from the extramural community than we currently have," says Cassman.

His committee also considered whether DRG should be placed under the authority of the deputy director for extramural research. But it failed to reach agreement. Although that would give authority over the largest body evaluating extramural research

to the individual directly responsible for the extramural research programme, some committee members feared it might also be seen as a demotion for the division.

This itself could complicate recruitment of a new DRG director to replace Jerome Greene, who stepped down from this post at the end of March. "In the end we decided to pass the buck [to Varmus]," says Cassman. Varmus says that, for the present, DRG will continue to answer directly to him.

Baldwin is now soliciting nominations for membership of the oversight panel, which is planned to be in operation within three months. Current plans call for 17 members, she says, the majority of whom will be extramural researchers.

\section{US cardiologist found guilty of theft}

Boston. Bernardo Nadal-Ginard, a worldrenowned cardiologist who formerly headed the cardiology department at Children's Hospital in Boston, has been found guilty on 12 counts of larceny for having stolen more than $\$ 117,000$ from the hospital and other organizations.

The verdict was reached after a threeweek trial and some 25 hours of deliberation by the jury. Last Monday ( 5 June), Nadal-Ginard was given a one-year jail sentence, with an additional term in state prison of three-and-a-half to fiveand-a-half years, suspended for five years, during which he will be required to carry out $\mathbf{4 0}$ hours a week of community service. In addition, the state medical board may revoke his licence to practise medicine.

Scott Harshbarger, the Massachusetts attorney general whose office prosecuted the case, described it as "a classic case of a person exploiting his position of trust for his own personal financial gain". He added: "White collar crime in the health care system costs us all; that's why it is critical we take a very hard line against it."

Harshbarger's office has still to decide whether to seek a retrial on $\mathbf{1 0}$ additional counts of larceny on which the jury was unable to reach a consensus. In all, the physician was accused of diverting $\$ 380,000$ for personal use (see Nature 367 , 401 ; 1994).

According to some reports, the jury became deadlocked on these charges partly because of claims by Nadal-Ginard and his attorneys that the embezzlement stemmed from a psychiatric condition, "Bipolar 2 mood disorder", from which he is said for have suffered for the past 30 years.

They maintained that severe mood swings made him unable to realize that he was committing a crime by taking money from the hospital and two nonprofit foundations, the Boston Children's Heart
In a separate initiative designed to keep abreast of the problems confronting biomedical researchers, Varmus has appointed a 14-member advisory committee to examine the threats to US clinical research. This panel will examine topics such as the growing difficulties in recruiting patients to clinical trials and in financing clinical research as more people join health maintenance organizations instead of traditional fee-for-service insurance plans.

The panel will also look at the changing role of academic clinical research centres, and the training of new clinical researchers. It will be chaired by David Nathan of Harvard Medical School and will hold its first meeting next month.

Robert Taylor

Foundation Inc. and the Cardiovascular Surgical Foundation.

This argument was not used, however, to defend Nadal-Ginard on the 12 charges on which he was convicted. The jury found him guilty of stealing money through a number of schemes from August 1991 to December 1992.

In one scheme, Nadal-Ginard deposited in his personal bank account five cheques made out to the cardiovascular foundation that were supposed to support research and laboratory equipment for children with heart disease.

In another, he used money from the Children's Heart Foundation to pay the salary of the head of a new biotechnology company in which he had invested. The jury also decided that Nadal-Ginard had used Heart Foundation money to make a personal contribution to a Boston museum.

In a civil trial which concluded last December, a US District Court judge ordered Nadal-Ginard to pay $\$ 6.5$ million to the Boston Children's Heart Foundation for withdrawing excessive compensation from a pension fund. That decision is under appeal.

Nadal-Ginard, meanwhile, is still technically on "medical leave" from his faculty post at Harvard Medical School. "We have full confidence in the integrity of the judicial process," said Harvard University spokesperson, Joe Wrinn. "The jury considered the evidence and reached its decisions which we respect." The university now plans to review NadalGinard's status at the medical school.

Harshbarger says that his office will "vigorously prosecute" such cases as a way of demonstrating that the law applies "equally to everyone, regardless of someone's socio-economic status".

Steve Nadis 